PINTO, Elizabeth Maria. Os gestos profissionais do docente da Educação Profissional Técnica de Nível Médio. 2020. 136f. Dissertação. Programa de Pós-Graduação Stricto Sensu do Mestrado em Educação Tecnológica. Diretoria De Pesquisa E Pós-Graduação, Centro Federal de Educação Tecnológica de Minas Gerais, Belo Horizonte, 2020. ${ }^{1}$

\title{
OS GESTOS PROFISSIONAIS DO DOCENTE DA EDUCAÇÃO PROFISSIONAL TÉCNICA DE NÍVEL MÉDIO
}

The professional gestures of the teacher of Medium-level Technical Professional Education

PINTO, Elizabeth Maria ${ }^{2}$

\section{RESUMO}

Esta dissertação apresenta o estudo sobre os gestos profissionais de um professor em prática educativa, em um laboratório de mecânica, em que os alunos realizam as atividades de montagem de um motor. No contexto, o professor orienta os alunos na execução de suas práticas, quando ocorre a manifestação de seu estilo profissional, a sua história, que se caracterizam em seus gestos profissionais. Essa revelação tem importância na qualidade da relação estabelecida com os alunos e com o processo de ensinar e aprender. A pesquisa foi realizada na abordagem qualitativa, sendo um estudo de caso, em uma perspectiva fenomenológica (MERLEAU-PONTY, 2011), considerando como base teórica os estudos sobre os gestos profissionais (JORRO, 1998, 2004, 2006, 2010, 2018, 2018a, 2018b, 2018c), desenvolvidos na França sobre o agir profissional, em gestos profissionais. Para tal, a revisão bibliográfica na literatura francesa sobre o tema permitiu o aprofundamento de seus estudos. Foi realizado um levantamento dos estudos no Brasil, identificando que o cenário das publicações até o momento dos estudos mostra-se pouco sobre o tema, o que permitiu ter novos olhares e fundamentos para a pesquisa. Na abordagem teórico-metodológica, organizou-se um cruzamento de técnicas, considerando a subjetividade que compõe a ação. Contou-se com a observação e as filmagens das aulas, e a entrevista em autoconfrontação simples (ANTIPOFF; LEAL; LIMA, 2018), que foram fundamentais para acompanhar e identificar as linguagens verbais e não verbais, os gestuais, a corporeidade e as singularidades no contexto da atuação do professor na atividade prática com os alunos. Os dados foram organizados em roteiro para análise nas entrevistas de autoconfrontação simples e semiestruturada, cruzando as técnicas definidas na metodologia. A entrevista simples de

\footnotetext{
${ }^{1}$ Orientadora: Maria Adélia da Costa, Doutora em Educação pela Universidade Federal de Uberlândia (UFU). Professora no Programa de Pós-graduação Mestrado em Educação Tecnológica (PPGET/CEFET-MG) e no Programa Especial de Formação Pedagógica de Docentes (PEFPD), Chefe do Departamento de Educação (DEDU), Líder do Pesquisadora do Grupo de Pesquisa e estudos Desenvolvimento Profissional Docente: entre o saber e o fazer na Educação Profissional e Tecnológica (DPRODEPT/CEFET-MG). E-mail: adelia.cefetmg@gmail.com

O presente trabalho foi realizado com apoio da Coordenação de Aperfeiçoamento de Pessoal de Nível Superior - Brasil (CAPES) - Código de Financiamento 001.

${ }^{2}$ Mestra em Educação Tecnológica (PPGET/CEFET-MG). Pedagoga pela PUC Minas. Pesquisadora do Grupo de Pesquisa e estudos Desenvolvimento Profissional Docente: entre o saber e o fazer na Educação Profissional e Tecnológica (DPRODEPT/CEFET-MG). Supervisora de Cursos na UTRAMIG. E-mail: elizapdg@yahoo.com.br
} 
autoconfrontação reforçou pontos e permitiu identificar a percepção do professor em suas verbalizações e clareou alguns pontos fundamentais para organização dos dados e categorização. Os dados foram analisados considerando os sentidos das atuações do professor e apreendidos os gestos profissionais, conforme as categorias estabelecidas, os sentidos de atuação e a matriz dos gestos profissionais (JORRO, 1998, 2004, 2006, 2010, 2018, 2018a, 2018b, 2018c). Identificou-se como gestos em sua ação: a postura do corpo e a corporeidade na realização do seu trabalho. Observou-se que é importante a percepção do professor sobre a identificação das ações e de seus gestos na dimensão subjetiva, no entrelaçamento de palavra, pensamento e ação em prática de trabalho docente, em um meio social de formação de alunos da EPTNM. Apreender os gestos profissionais em atuação permitiu ao docente conhecer a amplitude, intenção e valores de sua prática, de seu ofício em um contexto de ensino e aprendizagem. A presença da subjetividade e identidade é um olhar que vai além de seu trabalho prescrito, que considera a ação, o corpo em percepção e se expressa em gestos profissionais para a interação com o aluno, nas relações intersubjetiva em um mundo situado, nos significados para o outro, o que favorecem o ensino e aprendizagem em seus atos, gestos, discurso, história, conhecimento e meios sociais. $E$ isso evidencia a relevância dos estudos na academia brasileira, bem como a busca por ampliar a discussão sobre os gestos profissionais enquanto possibilidade de apreensão sobre as práticas do ofício e da apresentação da subjetividade do ator nestas práticas sociais.

Palavras-chave: Gestos profissionais, Gestos do ofício, Educação Profissional e Tecnológica, Corpo e Corporeidade, Ensino e Aprendizagem.

\section{ABSTRACT}

This dissertation presents the study about the professional gestures of a teacher in educational practice, in a mechanics laboratory, in which students perform the activities of assembling an engine. In this context, the teacher guides the students on the execution of their practices, when the manifestation of the teacher's professional style and history are characterized by the teacher's professional gestures. This revelation is important on the relationship quality established with the students and with the process of teaching and learning. The research was conducted in a qualitative approach, being a case study, in a phenomenological perspective (MERLEAU-PONTY, 2011), having as theoretical basis the professional gestures (JORRO, 1998, 2004, 2006, 2010, 2018, 2018a, 2018b, 2018c), developed in France about professional action, in professional gestures. To this end, the bibliographic review in the French literature about this subject allowed further studies. A survey about the studies realized in Brazil was carried out, identifying that the scenario of publications, up to this time, reveals little on the subject, which allowed having new perspectives and foundations to research. In the theoretical-methodological approach, a technical crossing was organized, considering the subjectivity that makes up the action. Classes observation and filming and interviews in simple self-confrontation (ANTIPOFF; LEAL; LIMA, 2018), were essential to accompany and identify the verbal and non-verbal speech, gestures, corporeality, and the singularities in the context of the teacher's performance in the practical activity with the students. The data were organized in a script for simple and semi-structured self-confrontation interviews analysis, crossing 
the techniques defined in the methodology. The simple self-confrontation interview reinforced points that made it possible to identify the teacher's perception in his verbalizations and clarified some fundamental points for data organization and categorization. The data analysis considered the directions of the teacher's actions and professional gestures apprehension, according to the established categories, the acting directions, and the matrix of the professional gestures (JORRO, 1998, 2004, 2006, 2010, 2018, 2018a, 2018b, 2018c). The following gestures were identified on the teacher's action: body posture and corporeality during work. It was observed that the teacher's perception about the identification of actions and gestures in the subjective dimension is important, in the intertwining of word, thought and action in teaching practice, in a social environment for the training of EPTNM students. Grasping the professional gestures in action allowed the teacher to understand the breadth, intention and values of teaching practice and craft in a context of teaching and learning. The presence of subjectivity and identity is an understanding which goes beyond its prescribed work, which takes action into account, the perceived body, and that is expressed in professional gestures for interaction with the student, in intersubjective relationships in a situated world, in the meanings for the other, what favors teaching and learning in their actions, gestures, discourse, history, knowledge and social media. And this highlights the relevance of studies in the Brazilian academy, as well as the pursuit to expand the discussion on professional gestures as a possibility of apprehension about the practices of the profession and the presentation of the actor's subjectivity in these social practices.

Keywords: Professional gestures. Professional and Technological Education. Teaching and Learning.

Data da submissão: 22/04/2021.

Data da aprovação: 08/05/2021. 